\title{
Is there a need to redefine the upper normal limit of TSH?
}

\author{
G Brabant, P Beck-Peccoz ${ }^{1}$, B Jarzab ${ }^{2}$, P Laurberg ${ }^{3}$, J Orgiazzi $^{4}$, I Szabolcs ${ }^{5}$, A P Weetman ${ }^{6}$ and W M Wiersinga ${ }^{7}$ \\ Abteilung Gastroenterologie, Hepatologie und Endokrinologie, Medizinische Hochschule, Hannover, Germany, ${ }^{1}$ Institute of Endocrine Sciences, University \\ of Milan, Ospedale Maggiore IRCCS, Padiglione Granelli, 20122-Milan, Italy, ${ }^{2}$ Department of Nuclear Medicine and Endocrine Oncology, Maria \\ Sklodowska-Curie Memorial Cancer Center and Institute of Oncology, Gliwice Branch, Poland, ${ }^{3}$ Department of Endocrinology and Medicine, Aalborg \\ Hospital, Aarhus University Hospital, DK-9000 Aalborg, Denmark, ${ }^{4}$ Service d'Endocrinologie Diabetologie, Centre Hospitalier Lyon Sud, Lyon, France, \\ ${ }^{5}$ Department of Internal Medicine, National Medical Center and Department of Dietetics, Semmelweis University, Budapest, Hungary, ${ }^{6}$ Clinical Sciences \\ Centre, Northern General Hospital, University of Sheffield, Sheffield, UK and ${ }^{7}$ Academisch Medisch Centrum, Universiteit van Amsterdam, Meibergdreef 9 , \\ 1105 AZ Amsterdam, The Netherlands
}

(Correspondence should be addressed to G Brabant; Email: georg.brabant@manchester.ac.uk)

\begin{abstract}
Mild forms of hypothyroidism - subclinical hypothyroidism - have recently been discussed as being a risk factor for the development of overt thyroid dysfunction and for a number of clinical disorders. The diagnosis critically depends on the definition of the upper normal limit of serum TSH as, by definition, free thyroxine serum concentrations are normal. Cut-off levels of $4-5 \mathrm{mU}$ TSH/l have been conventionally used to diagnose an elevated TSH serum concentration. Recent data from large population studies have suggested a much lower TSH cut-off with an upper limit of $2-2.5 \mathrm{mU} / \mathrm{l}$ but application of strict criteria for inclusion of subjects from the general population studies aiming at assessing TSH reference intervals (no personal or family history of thyroid disease, no thyroid antibodies and a normal thyroid on ultrasonography) did not result in an unequivocal upper limit of normal TSH at $2.0-2.5 \mathrm{mU} / \mathrm{l}$. When summarizing the available evidence for lowered upper TSH cut-off values and their potential therapeutic implications there is presently insufficient justification to lower the upper normal limit of TSH and, for practical purposes, it is still recommended to maintain the TSH reference interval of $0.4-4.0 \mathrm{mU} / \mathrm{l}$. Classifying subjects with a TSH value between 2 and $4 \mathrm{mU} / \mathrm{l}$ as abnormal, as well as intervening with thyroxine treatment in such subjects, is probably doing more harm than good.
\end{abstract}

European Journal of Endocrinology $154633-637$

\section{Introduction}

Serum thyrotrophin (TSH) showing a log-linear relationship to free thyroxine over a wide concentration range is commonly accepted as the most sensitive test to detect minor degrees of primary thyroid hormone deficiency (1). An elevated serum TSH level associated with normal free thyroxine serum concentrations is defined as subclinical hypothyroidism and has recently been discussed as being an important risk factor for the development of overt thyroid dysfunction and for a number of clinical, mainly cardiovascular, cognitive and psychiatric disorders (2). It is evident that the diagnosis of subclinical hypothyroidism critically depends on the definition of the upper normal TSH serum concentration. Cut-off levels of 4-5 mU TSH/l are conventionally used but a much lower upper limit of TSH was recently suggested. In this paper, we formally discuss the definition of subclinical hypothyroidism and the pros and cons of changing current cut-off TSH levels with respect to evidence-based benefits of a therapeutic intervention.

\section{Definition of 'normal' TSH values}

The definition of a 'normal' TSH level is not trivial. 'Normal', 'reference' and/or 'discrimination' values are commonly used to define the interval with which a measured TSH level is then compared. However, defining 'normal' as absolute health in a population free of disease has been heavily criticized as being far too simplistic because it implies that everything not being normal ought to be corrected (3). These problems have been circumvented by the definition of 'reference' values, implicating that absolute health does not exist. Following this approach, specifications are made to define a large population of subjects apparently free of thyroid disorders. These specifications comprise environmental and physiological conditions 
under which the specimens were obtained, the techniques and timing of specimen collection, their preparation and storage and the analytical and the statistical methods used for computation of these reference intervals from the data set (4). Finally, the term 'discrimination' values is coined to determine cut-off values important for medical decisions which require knowledge of the disease under consideration, its prevalence, the sensitivity and specificity of diagnostic tests, and the clinical consequences of a false positive or negative diagnosis (5).

\section{Methodological considerations}

Variations in the results of thyroid function tests in a healthy population may be due to analytical, intra-individual and inter-individual variations. Even though analytical variations are generally low, it must be considered that TSH is circulating in various isoforms differing in their bioactivity predominantly through changes in the glycosylation pattern (6). Detailed studies of the dependency of TSH bioactivity on hypothalamic thyrotrophin-releasing hormone clearly demonstrate the clinical importance of TSH glycosylation (7) and explain the apparently normal immunoreactive TSH levels in some hypothyroid patients with a hypothalamic defect of the hypothalamo-pituitarythyroid axis. Moreover, this heterogeneity may induce problems in the standardization of TSH measurements, which may explain differences of around $30-40 \%$ in TSH values due to assay technology (8) and, among other reasons, led the board of the recently published laboratory guidelines of the National Academy of Clinical Biochemistry (NACB) to propose laboratory-specific rigorous internal and external quality control for TSH measurement (1).

The intra-individual coefficient of variance (CV) for each thyroid function test exceeds the analytical CV. Recent data on the individual set-point of TSH in a group of apparently healthy subjects measured at monthly intervals indicate that the intra-individual variation is only half of that of the group. Thus, whereas analytical factors using modern TSH test instruments usually contribute less than $10 \%$ to the total variation, within-person variation may add around $20 \%$ and between-person variation up to $70 \%$ (9). Inter-individual variation may be partly genetically determined (10). The ratio of intra-individual to interindividual variation (the individuality index) has been used to estimate the usefulness of population-based reference ranges and a ratio of less than 0.6 indicates that the population-based reference range is not sensitive enough to discriminate between health and disease on an individual basis, whereas a ratio greater than 1.4 is regarded as discriminatory $(11,12)$. For TSH, the index of individuality was below 0.6 in three studies, varying between 0.36 and $0.5(9,11,12)$, thus indicating that TSH values within the reference interval but close to the lower or upper limits of normal may not necessarily indicate a normal thyroid function.

\section{The influence of physiological, pathological and pharmacological factors}

A number of physiological and pathophysiological conditions may alter the pattern of TSH secretion. Acute sleep withdrawal considerably stimulates the nocturnal (and morning) levels of TSH as does acute stress or high physical activity, which all induce an acute two- to fourfold rise in serum TSH levels (13). Genetic influences play a role in the hypothalamo-pituitary setpoint and these alterations in physiological TSH levels may translate into subtle changes in energy homeostasis reflected in body mass index (14). Non-thyroidal illness is associated with suppressed TSH secretion and a decrease in serum tri-iodothyronine levels, but may result in an increased serum TSH level above $4 \mathrm{mU} / \mathrm{l}$ during the recovery period (15). Furthermore, a large number of nutritional factors and drugs may acutely or chronically affect TSH secretion. Whereas the effects of iodine supply are regarded to be small, experimental evidence in healthy subjects clearly demonstrates that short-time alterations in iodide availability may change TSH considerably with a doubling of TSH levels 3 weeks after iodine treatment (16). Finally, a number of non-thyroidal drugs such as metoclopramide, somatostatin analogues, dopamine, glucocorticoids or sulpiride may affect TSH secretion, whereas the increase in thyroxine-binding globulin by oestrogens induces a much slower and smaller rise in TSH over days to weeks (1). All these factors may contribute to the high rate of spontaneous normalization of elevated TSH serum levels $(>5 \mathrm{mU} / \mathrm{l})$ recently reported in patients with subclinical hypothyroidism (17).

\section{Reference values from population studies}

It has recently been discussed as to whether the higher TSH reference value should be set around $2.5 \mathrm{mU} / \mathrm{l}$ instead of the customary $4 \mathrm{mU} / \mathrm{l}$. In the National Health and Nutrition Examination Survey (NHANES III), representing the geographic and ethnic distribution of the US population, the median and 2.5-97.5 centiles of serum TSH were $1.39 \mathrm{mU} / \mathrm{l}$ (0.45-4.12) in the reference population of 13344 people (defined as the population excluding people who reported thyroid disease, goiter or who were taking thyroid medication, and also excluding people because of pregnancy, the use of sex steroids or lithium, thyroid antibodies and biochemical hypo-or hyperthyroidism (18). TSH serum levels showed a skewed distribution with a relatively long 'tail' towards higher TSH levels. It has been argued that subjects belonging 
to this 'tail' (with TSH levels $>2.5 \mathrm{mU} / \mathrm{l}$ ) still have subclinical thyroid disease which might have been detected by the use of thyroid ultrasound and more sensitive assays of thyroid antibodies; thus the 'true' upper normal limit of TSH would be $2.5 \mathrm{mU} / \mathrm{l}$ (19). Indeed, the Study of Health in Pomerania (SHIP-1), an area in Germany with previous iodine deficiency, reported a TSH reference interval of $0.25-2.12 \mathrm{mU} / \mathrm{l}$ in a reference population of 1488 subjects, applying the same criteria as the NHANES III survey but also excluding people with abnormalities on thyroid ultrasound (20). In contrast, another study from Germany in 453 healthy blood donors with ultrasonographically assessed normal thyroid glands and selected as recommended by the NACB, reports a TSH reference interval of $0.40-3.77 \mathrm{mU} / \mathrm{l}(21)$. Also in a Danish study a TSH reference range of $0.40-3.6 \mathrm{mU} / \mathrm{l}$ was found in 3174 participants without previous thyroid disease, without TPO antibodies and with a normal thyroid by ultrasonography (22), and a recent large Danish study defined the upper normal limit of TSH as $4.5 \mathrm{mU} / \mathrm{l}(23)$.

Thus, the only study so far providing direct data to support an upper normal TSH limit of $2.0-2.5 \mathrm{mU} / \mathrm{l}$ is the SHIP-1 study (20). However, despite their proper exclusion criteria, the SHIP-1 study probably still included people with autonomous functioning areas in the thyroid as judged from the fall in median TSH values with age - probably reflecting the previously moderately severe iodine deficiency in the Pomeranian population; for comparison, the TSH values clearly increased with age in the NHANES III study. Furthermore, the TSH assay applied in the SHIP-1 study has a low TSH reference interval of $0.3-3.0 \mathrm{mU} / \mathrm{l}$ as stated by the manufacturer, once more underlining differences in performance of TSH assays even if calibrated against the same international reference preparation (8). Hence the outcome of most studies is still in accordance with the customary TSH reference interval of $0.4-4.0 \mathrm{mU} / \mathrm{l}$.

\section{Clinical aspects and health hazards of subclinical hypothyroidism}

Mild thyroid failure is often asymptomatic but around $30 \%$ of patients with this condition may have symptoms suggestive of thyroid hormone deficiency. However, in the Colorado Thyroid Disease Prevalence Study (24) the difference in the prevalence of symptoms between euthyroid controls $(12.1 \%)$ and subjects with subclinical hypothyroidism $(13.7 \%)$ was marginal. From these data (defining subclinical hypothyroidism as TSH serum levels $>5.1 \mathrm{mU} / \mathrm{l}$ ) it appears unlikely that differences in the prevalence of clinical symptoms can be expected when people with TSH levels between 2.5 and $4.5 \mathrm{mU} / \mathrm{l}$ are compared with people with TSH concentrations in the range $0.4-2.5 \mathrm{mU} / \mathrm{l}$. There is still dispute about the benefits of treating subclinical hypothyroidism with levothyroxine when serum TSH is below $10 \mathrm{mU} / \mathrm{l}$ (24), and good data are lacking on the effect of levothyroxine when serum TSH levels are in the range $2.5-4.0 \mathrm{mU} / \mathrm{l}$.

In the Whickham study, a large 20-year populationbased prospective cohort study from the UK, development of overt hypothyroidism was only observed in subjects with TSH serum levels $>2 \mathrm{mU} / \mathrm{l}$ at initial investigation, supporting the importance of a lower TSH cut-off (25). This is in contrast to a rigorously controlled study from Switzerland over a follow-up period of 18 years which suggests that only subjects with an initial TSH serum level above $6 \mathrm{mU} / \mathrm{l}$ are at risk of developing hypothyroidism but not when serum TSH was below $6 \mathrm{mU} / \mathrm{l}$ (26). Furthermore, evaluation of life hazards from the Whickham study does not provide evidence that treatment of subjects with TSH values between 2.5 and $4.0 \mathrm{mU} / \mathrm{l}$ improves short-term or long-term outcome. In the 20-year follow-up, no association between positive thyroid antibodies or raised serum TSH at first survey and subsequent mortality or development of ischaemic heart disease was found $(25,27)$.

However, the well-known association between cholesterol and TSH levels and vascular risks has been evaluated in some studies focusing on serum TSH levels between 2.5 and $4 \mathrm{mU} / \mathrm{l}$. In hypercholesterolaemic patients with normal TSH values (all between 0.4 and $4.0 \mathrm{mU} / \mathrm{l}$ ), who were randomized to receive either $25 \mu \mathrm{g}$ or $50 \mu \mathrm{g}$ thyroxine daily, serum total and low density lipoprotein cholesterol decreased only in the group with TSH values between 2.0 and $4.0 \mathrm{ml}$ (28). Intima media thickness has been used as another marker to estimate the risk of arteriosclerosis. Michalopoulou et al. (29) in a recent survey demonstrated an increased intima media thickness in subclinical hypothyroidism when defined as TSH $>4.5 \mathrm{mU} / \mathrm{l}$. This is in contrast to findings from the SHIP-1 data base indicating a decreased rather than increased intima media thickness in mild forms of hypothyroidism (30). Small intervention studies further evaluated a potential difference when lower TSH cut-off values are applied. Subjects with a serum TSH between 2.0 and $4.0 \mathrm{mU} / \mathrm{l}$ but not those with TSH values between 0.4 and $2.0 \mathrm{mU} / \mathrm{l}$ demonstrated impaired vasodilatation which positively responded to thyroxine treatment $(31,32)$. This may provide a pathophysiological explanation for the increased cardiovascular risk in the Rotterdam study of ageing females in whom subclinical hypothyroidism was defined as a cut-off TSH level $>4.5 \mathrm{mU} / \mathrm{l}$ and fits with a large body of studies showing impaired myocardial function in subclinical hypothyroidism (33-36). All changes may be reversible when thyroxine replacement is started $(35,36)$ but no data have been published on a comparison of a TSH threshold of 4.5 vs $2.5 \mathrm{mU} / \mathrm{l}$. 


\section{Hazards in supplementing subclinical hypothroidism}

Overzealous treatment with thyroxine may suppress serum TSH, producing overt or, more usually, subclinical hyperthyroidism. Abnormally low TSH values $(<0.3 \mathrm{mU} / \mathrm{l})$ have been found in $10-33 \%$ of individuals on thyroxine therapy and approximately onethird to one-half of these TSH levels were less than $0.1 \mathrm{mU} / \mathrm{l}(24,37,38)$. A too high dose of exogenous thyroxine matches the clinical outcome in endogenous subclinical hyperthyroidism. In the Colorado Thyroid Disease Prevalence Study, 92\% of subjects had seen a physician in the preceding year, yet $40 \%$ of the patients on thyroxine therapy had an abnormal TSH level, including $22 \%$ with a low $\operatorname{TSH}(24,38)$. Over-replacement of thyroxine in primary hypothyroidism was the most common cause of suppressed TSH in some studies and this was corrected in only $11 \%$ of the subjects under routine clinical conditions (38). Many groups have provided convincing evidence that 'subclinical' hyperthyroidism may induce relevant signs and symptoms of excessive thyroid hormone action, including morphological changes of the heart and a higher risk of supraventricular arrhythmias $(2,36,40)$. These abnormalities may precede the onset of more severe cardiovascular disease, thus potentially explaining the increased cardiovascular morbidity and mortality observed $(36,37)$. The potential benefits of correcting subclinical hypothyroidism should thus be balanced against the fact that our record in delivering optimal treatment to those who unequivocally need it is not, so far, very good (41).

\section{No compelling need to lower the upper normal limit of TSH}

In summary, despite some arguments that the upper normal limit of TSH might be lowered to $2.5 \mathrm{mU} / \mathrm{l}$ $(40,41)$, no firm evidence is available that introducing this limit will provide any short- or long-term benefit for the patient. Moreover, classifying approximately $5 \%$ of the population as possibly abnormal may create a large burden, financially to the society and emotionally to the subjects involved. Lowering the upper limit of normal serum TSH levels from $4-5 \mathrm{mU} / \mathrm{l}$ to $2.5 \mathrm{mU} / \mathrm{l}$ will also substantially increase the risk of thyroxine overtreatment, resulting in the well-known and evidence-based risks of subclinical hyperthyroidism (see also 27). Furthermore, the assumption that TSH truly reflects thyroid status in every organ system is most likely erroneous. This implies that titration of thyroxine dose according to two narrow boundaries of TSH values may increase the risk of organ-specific overtreatment (38). Thus, despite the fact that individual patients with subclinical hypothyroidism and a TSH level between 2.5 and $4 \mathrm{mU} / \mathrm{l}$ may theoretically profit from a limited, well-controlled therapeutic trial with thyroxine, we do not recommend the lowering of the upper normal TSH limit on the basis of currently available data. This may not apply to patients who are already on thyroxine for hypothyroidism, in whom the original set-point of TSH can never be known. In such patients who have symptoms despite a TSH level within the upper part of the reference range, it may be worthwhile trying a slightly higher dose of thyroxine to bring the TSH into the lower half of the reference range below $2.5 \mathrm{mU} / \mathrm{l}$ before concluding that hypothyroidism is not responsible for the clinical symptomatology.

\section{References}

1 Demers LM \& Spencer CA. Laboratory support for the diagnosis and monitoring of thyroid disease. NACB guidelines http://www. nacb.org/lmpg/thyroid_lmpg_pub.stm. Clinical Endocrinology 200353 138-140.

2 Surks MI, Ortiz E, Daniels GH, Sawin CT, Col NF, Cobin RH, Franklyn JA, Hershman JM, Burman KD, Denke MA, Gorman C, Cooper RS \& Weissman NJ. Subclinical thyroid disease: scientific review and guidelines for diagnosis and management. Journal of the American Medical Association $2004291228-238$.

3 Benson ES. The concept of the normal range. Human Pathology $19723152-155$.

4 Sunderman FW. Current concepts of 'normal values', 'reference values', and 'discrimination values' in clinical chemistry. Clinical Chemistry 1975214 1873-1877.

5 Malvano R, Chiecchio A, Borsa M \& Messeri G. The uncertainty associated with the predictive value of test results. Clinical Chemistry: Laboratory Medicine 199836 463-468.

6 Szkudlinski MW, Fremont V, Ronin C \& Weintraub BD. Thyroidstimulating hormone and thyroid-stimulating hormone receptor structure-function relationships. Physiological Reviews 200282 473-502.

7 Beck-Peccoz P, Amr S, Menezes-Ferreira MM, Faglia G \& Weintraub BD. Decreased receptor binding of biologically inactive thyrotropin in central hypothyroidism. Effect of treatment with thyrotropin-releasing hormone. New England Journal of Medicine $19853121085-1090$.

8 Rawlins ML \& Roberts WL. Performance characteristics of six third-generation assays for thyroid-stimulating hormone. Clinical Chemistry $2004502338-2344$.

9 Browning MCK, Ford RP, Callaghan SJ \& Fraser CG. Intra- and interindividual biological variation of five analytes used in assessing thyroid function: implications for necessary standards of performance and the interpretation of results. Clinical Chemistry $198632962-966$.

10 Hansen PS, Brix TH, Sorensen TI, Kyvik KO \& Hegedus L. Major genetic influence on the regulation of the pituitary-thyroid axis: a study of healthy Danish twins. Journal of Clinical Endocrinology and Metabolism $2004891181-1187$.

11 Andersen S, Bruun NH, Pedersen KM \& Laurberg P. Biologic variation is important for interpretation of thyroid function tests. Thyroid 200313 1069-1078.

12 Harris EK. Effects of intra- and interindividual variation on the appropriate use of normal ranges. Clinical Chemistry 199420 $1535-1542$.

13 Brabant G, Brabant A, Ranft U, Ocran K, Kohrle J, Hesch RD \& von zur Muhlen A. Circadian and pulsatile thyrotropin secretion in euthyroid man under the influence of thyroid hormone and glucocorticoid administration. Journal of Clinical Endocrinology and Metabolism $1987 \mathbf{6 5} 83-88$. 
14 Knudsen N, Laurberg P, Rasmussen LB, Bulow I, Perrild H, Ovesen L \& Jorgensen T. Small differences in thyroid function may be important for body mass index and the occurrence of obesity in the population. Journal of Clinical Endocrinology and Metabolism $2005904019-4024$.

15 Adriaanse R, Romijn JA, Brabant G, Endert E \& Wiersinga WM. Pulsatile thyrotropin secretion in nonthyroidal illness. Journal of Clinical Endocrinology and Metabolism 199377 1313-1317.

16 Brabant G, Bergmann P, Kirsch CM, Kohrle J, Hesch RD \& von zur Muhlen A. Early adaptation of thyrotropin and thyroglobulin secretion to experimentally decreased iodine supply in man. Metabolism 199241 1093-1096.

17 Diez JJ, Iglesias P \& Burman KD. Spontaneous normalization of thyrotropin concentrations in patients with subclinical hypothyroidism. Journal of Clinical Endocrinology and Metabolism 200590 4124-4127.

18 Hollowell JG, Staehling NW, Flanders WD, Hannon WH, Gunter EW, Spencer CA \& Braverman LE. Serum TSH T(4), and thyroid antibodies in the United States population (1988-1994): National Health and Nutrition Examination Survey (NHANES III). Journal of Clinical Endocrinology and Metabolism 200287 486-488.

19 Baloch Z, Carayon P, Conte-Devoix B, Demers LM, FeldtRasmussen U, Henry JF, LiVosli VA, Niccoli-Sire P, John R, Ruf J, Smyth PP, Spencer CA \& Stockigt JR. Laboratory support for the diagnosis and monitoring of disease. Thyroid 200313 3-126.

20 Volzke H, Ludemann J, Robinson DM, Spieker KW, Schwahn C, Kramer A, John U \& Meng W. The prevalence of undiagnosed thyroid disorders in a previously iodine-deficient area. Thyroid $200313803-810$.

21 Kratsch J, Fiedler GM, Leichtle A, Brugel M, Buchbinder S, Otto L, Sabri O, Matthes G \& Thiery J. New reference intervals for thyrotropin and thyroid hormones based on National Academy of Clinical Biochemistry criteria and regular ultrasonography of the thyroid. Clinical Chemistry $2005 \mathbf{5 1}$ 1480-1486.

22 Knudsen N, Bulow I, Jorgensen T, Laurberg P, Ovesen L \& Perrild H. Comparative study of thyroid function and types of thyroid dysfunction in two areas in Denmark with slightly different iodine status. European Journal of Endocrinology $2000143485-491$.

23 Jensen E, Hyltoft Petersen P, Blaabjerg O, Hansen PS, Brix TH, Kyvik KO \& Hegedus L. Establishment of a serum thyroid stimulating hormone (TSH) reference interval in healthy adults. The importance of environmental factors, including thyroid antibodies. Clinical Chemistry: Laboratory Medicine 200442 824-832.

24 Canaris GJ, Manowitz NR, Mayor G \& Ridgway EC. The Colorado Thyroid Disease Prevalence study. Archives of Internal Medicine $2000160526-534$.

25 Vanderpump MPJ, Tunbridge WMG, French JM, Appleton D, Bates D, Clark F, Grimley Evans J, Hasan DM, Rodgers H \& Tunbridge F. The incidence of thyroid disorders in the community: a twenty-year follow-up of the Whickham Survey. Clinical Endocrinology $19954355-68$.

26 Huber G, Staub JJ, Meier C, Mitrache C, Guglielmetti M, Huber P \& Braverman LE. Prospective study of the spontaneous course of subclinical hypothyroidism: prognostic value of thyrotropin, thyroid reserve, and thyroid antibodies. Journal of Clinical Endocrinology and Metabolism 200287 3221-3226.

27 Surks MI, Goswami G \& Daniels GH. The thyrotropin reference range should remain unchanged. Journal of Clinical Endocrinology and Metabolism $2005905489-5496$.

28 Zulewski H, Muller B, Exer P, Miserez AR \& Staub JJ. Estimation of tissue hypothyroidism by a new clinical score: evaluation of patients with various grades of hypothyroidism and controls. Journal of Clinical Endocrinology and Metabolism 199782 771-776.

29 Michalopoulou G, Alevizaki M, Piperingos G et al. High serum cholesterol levels in persons with 'high-normal' TSH levels: should one extend the definition of subclinical hypothyroidism? European Journal of Endocrinology 1998138 141-145.

30 Taddei S, Caraccio N, Virdis A, Dardano A, Versari D, Ghiadoni L, Salvetti A, Ferrannini E \& Monzani F. Impaired endotheliumdependent vasodilatation in subclinical hypothyroidism: beneficial effect of levothyroxine therapy. Journal of Clinical Endocrinology and Metabolism $2003 \mathbf{8 8} 3731-3737$.

31 Volzke H, Robinson DM, Schminke U, Ludemann J, Rettig R, Felix SB, Kessler C, John U \& Meng W. Thyroid function and carotid wall thickness. Journal of Clinical Endocrinology and Metabolism $2004892145-2149$.

32 Lekakis L, Papamichael C, Alevizaki M, Piperingos G, Marafelia P, Mantzos J, Stamatelopoulos S \& Koutras DA. Flow-mediated, endothelium-dependent vasodilatation is impaired in subjects with hypothyroidism, borderline hypothyroidism, and highnormal serum thyrotropin (TSH) values. Thyroid $1997 \quad 7$ $411-414$.

33 Hak AE, Pols HA, Visser TJ, Drexhage HA, Hofman A \& Witteman JC. Subclinical hypothyroidism is an independent risk factor for atherosclerosis and myocardial infarction in elderly women: the Rotterdam Study. Annals of Internal Medicine 2000 $132270-278$.

34 Biondi B, Palmieri EA, Klain M, Schlumberger M, Filetti S \& Lombardi G. Subclinical hyperthyroidism: clinical features and treatment options. European Journal of Endocrinology 2005152 1-9. 35 Imaizumi M, Akahoshi M, Ichimaru S, Nakashima E, Hida A, Soda M, Usa T, Ashizawa K, Yokoyama N, Maeda R, Nagataki S \& Eguchi K. Risk for ischemic heart disease and all-cause mortality in subclinical hypothyroidism. Journal of Clinical Endocrinology and Metabolism 200489 3365-3370.

36 Kahaly GJ \& Dillmann WH. Thyroid hormone action in the heart. Endocrine Reviews 200526 704-728.

37 Franklyn JA, Sheppard MC \& Maisonneuve P. Thyroid function and mortality in patients treated for hyperthyroidism. Journal of the American Medical Association 2005294 71-80.

38 Ross DS, Daniels GH \& Gouveia D. The use and limitations of a chemiluminescent thyrotropin assay as a single thyroid function test in an outpatient endocrine clinic. Journal of Clinical Endocrinology and Metabolism 199071 764-769.

39 Chu JW \& Crapo LM. The treatment of subclinical hypothyroidism is seldom necessary. Journal of Clinical Endocrinology and Metabolism $2001864591-4599$.

40 Parle JV, Maisonneuve P, Sheppard MC, Boyle P \& Franklyn JA. Prediction of all-cause and cardiovascular mortality in elderly people from one low serum thyrotropin result: a 10-year cohort study. Lancet $20013 \mathbf{3 5 8} 861-865$.

41 Romijn JA, Smit JW \& Lamberts SW. Intrinsic imperfections of endocrine replacement therapy. European Journal of Endocrinology 2003149 91-97.

42 Wartofsky L \& Dickey RA. The evidence for a narrower thyrotropin reference range is compelling. Journal of Clinical Endocrinology and Metabolism $2005905483-5488$.

43 Jaeschke R, Guyatt G, Gerstein H, Patterson C, Molloy W, Cook D, Harper S, Griffith L \& Carbotte R. Does treatment with L-thyroxine influence health status in middle-aged and older adults with subclinical hypothyroidism? Journal of General Internal Medicine 1996 $11744-749$.

44 Nystrom E, Caidahl K, Fager G, Wikkelso C, Lundberg PA \& Lindstedt G. A double-blind cross-over 12-month study of L-thyroxine treatment of women with 'subclinical' hypothyroidism. Clinical Endocrinology 198829 63-75.

Received 12 September 2005

Accepted 7 February 2006 